\title{
Molecular Basis for Detection of Invading Pathogens in the Brain
}

\author{
Jeppe Falsig, ${ }^{1 \star}$ Johan van Beek, ${ }^{2}$ Corinna Hermann, ${ }^{3}$ and Marcel Leist ${ }^{3}$ \\ 'Institute of Neuropathology, Universitaetsspital Zürich, Zuerich, Switzerland \\ ${ }^{2}$ Experimental Pharmacology, Merck Serono International S.A., Geneva, Switzerland \\ ${ }^{3}$ Department of Natural Sciences, University of Konstanz, Konstanz, Germany
}

\begin{abstract}
Classical immunology textbooks have described the central nervous system as an immune-privileged site, i.e., as devoid of inflammatory and host-vs.-graft immunoreactions. This view has been refined, since we now know that hematopoietic cells infiltrate the CNS under certain circumstances and that CNS-resident cells are capable of launching an innate immune response. Microglia cells express an extensive repertoire of pattern-recognition receptors and act as sentinels surveilling the CNS for possible damage or infection. Astrocytes are the most abundant cell type in the brain, and they are capable of launching a strong supportive innate immune response. Novel findings show that both astrocytes and, surprisingly, even neurons express pattern-recognition receptors. Activation of these receptors leads to a functional response, indicating that cells other than microglia are capable of initiating a primary innate immune response against CNS-invading pathogens. Here, we put these findings into context with what has been learned from recent in vitro and in vivo experiments about the initiation of an innate immune response in the brain.
\end{abstract}

Key words: pathogen-associated molecular patterns; pattern recognition receptors; microglia; CNS; astrocytes

Historically, the CNS was described as an immune-privileged site based on the tolerance of the brain to a skin graft (Medawar, 1948). In addition, the brain appeared to lack a draining lymphatic system, combined with the presence of a blood-brain barrier and a low expression of major histocompatibility complex (MHC) molecules on CNS-resident cells. In recent years, this view has been altered dramatically, and we now know that peripheral immune cells can migrate into the brain and affect the course of CNS diseases or even be major players in neuropathological events (Becher et al., 2006; Simard et al., 2006; Priller et al., 2006). Cell infiltration is often limited to the vessel walls or perivascular spaces (Bechmann et al., 2007), and CNS-residing cells regulate the entry of blood-borne immune cells into the brain parenchyma and modulate their response, be it adaptive or innate. This is partially achieved by the release of pro- and antiinflammatory cytokines and chemokines capable of attracting peripheral immune cells (Heppner et al., 2005; Owens et al., 2001). In addition, CNS cells can regulate the survival of infiltrating cells once they have entered the brain parenchyma. A more accurate term would be to describe the CNS as an "immune-attenuated" site. References on the function of CNS-infiltrating immune cells can be found elsewhere (Becher et al., 2006; Simard et al, 2006; Bechmann et al., 2007). Here, we describe how CNS-resident cells detect microorganisms and initiate an innate immune response.

\section{PATTERN RECOGNITION RECEPTORS}

Pattern recognition receptors (PRRs; Fig. 1) are a group of evolutionarily conserved receptor families capable of detecting pathogen-associated molecular patterns (PAMPs). PAMPs are molecular structures with certain physicochemical characteristics, usually in a repetitive/ polymeric form, that are recognized by PRR instead of chemically defined epitopes (Medzhitov and Janeway, 2002; Akira et al., 2006). The most studied PRRs are the Toll-like-receptors (TLRs). Other membrane PRRs are the scavenger receptor family, the receptor for advanced glycation-endproducts (RAGE), and C-type lectin receptors (Stahl and Ezekowitz, 1998; Murphy et al., 2005). The complement system comprises another type of

Contract grant sponsor: Zentrum für Neurowissenschaften Zürich (ZNZ; to J.F.); Contract grant sponsor: Desirec and Niels Yde Foundation (to J.F.); Contract grant sponsor: Henny Sophie Clausen og møbelarkitekt Axcl Clausens Foundation (to J.F.); Contract grant sponsor: Ivan Nielsens Foundation (to J.F.).

*Correspondence to: Jeppe Falsig, Institute of Neuropathology, Universitaetsspital Zürich, Schmelzbergstrasse 12, 8091 Zuerich, Switzerland. E-mail: jeppefalsig.pedersen@usz.ch 


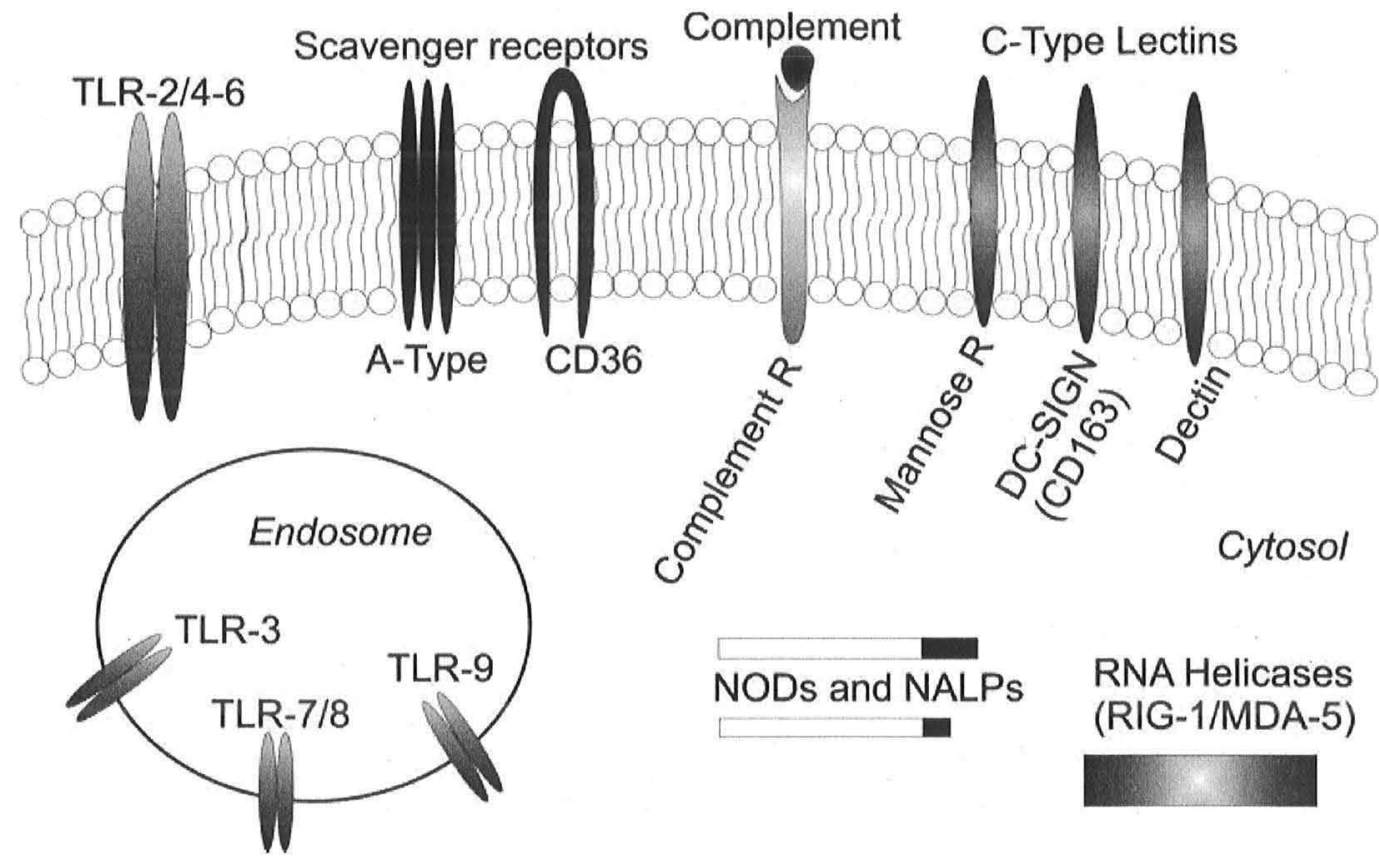

Fig. 1. Different types of pathogen-recognition receptors and their subcellular localization. Toll-like receptors (TLRs) are found on the cell surface and on the membrane of intracellular organelles, where they recognize internalized PAMPs; scavenger receptors are a heterogencous group of receptor families (types $\mathrm{A}-\mathrm{H}$ ) characterized by the unifying property to bind to oxidized LDL. CD36 is an example of a B-type scavenger receptor; complement receptors (complement R) act together with their primary ligand, activated complement factors

extracellular PRRs, where the membrane signaling components (i.e., the complement receptors) are dissociated from the detection and effector component (soluble complement factors). In addition, several intracellular PRRs have been identified, capable of detecting PAMPs in different intracellular compartments (Meylan et al., 2006).

\section{The TLRs}

Ten members of the TLR family (Medzhitov and Janeway, 2002) have been identified in humans and 12 in mice (Akira et al., 2006). Toll, the initial member of the TLR family, was first identified in Drosophila melanogaster as a type- 1 receptor with an intracellular domain similar to that of the interleukin-1 receptor. Mutation of the Toll receptor and the downstream signaling compo-

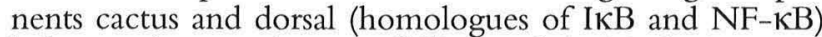
led to an increased susceptibility to fungal infections and decreased survival upon fungal infection (Lemaitre et al. 1996). TLRs are glycosylated type-1 integral membrane proteins with a molecular mass ranging from 90 to 115 $\mathrm{kDa}$. TLRs can be divided into subgroups based on the molecules that they recognize. For instance, TLR1, TLR2, TLR4, and TLR6 recognize modified lipids; TLR5 recognizes bacterial flagellin; and TLR11 recog- bound to pathogens, as pathogen recognition receptors; C-type lectins recognize mainly sugar polymers and represent a heterogencous, growing class of receptors; nucleotide-binding oligomerization domain (NOD) proteins comprise different NOD members, including NALP, and recognize intracellular bacterial products in the cytosol; also involved in intracellular recognition are RNA-helicase related proteins such as retinoic-inducible protein-1 (RIG-1)/melanoma differentiation-associated protein-5 (MDA-5).

nizes profilin-like molecules from Toxoplasma gondii (for a more extensive review on TLR ligands see Akira et al., 2006, and Fig. 2). Some TLRs display high ligand selectivity. TLR3 recognizes viral double-stranded RNA; TLR7 and TLR8 recognize single stranded viral RNA; and TLR9 recognizes viral DNA and bacterial nonmethylated $\mathrm{CpG}$-containing DNA motifs. Other receptors are much less selective in their ligand recognition. TLR2 and TLR4 recognize a wide variety of lipids, glycolipids, and envelope proteins. They can even be stimulated by host-derived molecules such as chaperones or S100 proteins (Akira et al., 2006) and may thus take a role in chronic neurodegeneration and regenerative processes in the brain (Rolls et al., 2007; Tang et al., 2007).

TLRs are associated as hetero- and homodimers in the absence of ligands, interacting via their extracellular domains (Ozinsky et al., 2000; Mizel et al., 2003). The cellular response to stimulation with a given ligand depends strongly on the TLR receptor composition. Activation of homodimerized TLR4 triggers a signaling cascade that ultimately leads to the production of tumor necrosis factor (TNF) in macrophages. In contrast, activation of homodimerized TLR1, TLR2, or TLR6 does not. However, stimulation of heterogeneous receptor complexes consisting of TLR2 dimerized with either 


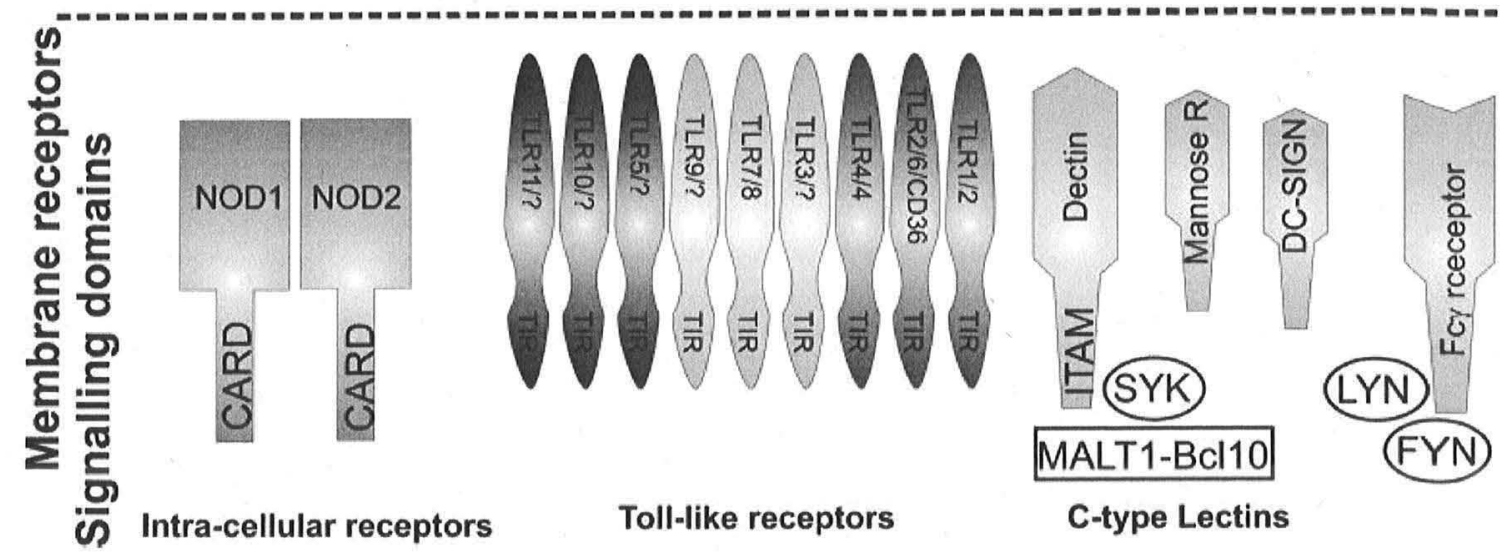

Fig. 2. Pathogen recognition receptors couple pathogen-derived ligands to the cellular signal transduction machinery. The receptors are shown with their cognate ligands. The protein domain essential for signal transduction is indicated in the bottom part of the receptors. For the ITAM-containing receptors, some examples of essential transducers are shown. MDP, muramyl dipeptide; LPS, lipopolysaccharide; LP, lipopeptide; LTA, lipoteichoic acid; iE-DAP, gammaD-glutamyl-mesodiaminopimelic acid; CpG, demethylated DNA rich

TLR1 or TLR6 does lead to the production of TNF (Ozinsky et al., 2000). TLRs are expressed predominantly on the cell surface, but the nucleic acid-detecting receptors TLR3, TLR7, TLR8, and TLR9 are also highly expressed on endosomes. The ratio of relative surface to endosomal expression varies for different cell types (Ozinsky et al., 2000; Akira et al., 2006).

\section{TLR Signal Transduction}

The complexity of TLR signaling is increased by the fact that other coreceptors are involved in the binding and signaling of PAMPs. Lipopolysaccharide (LPS), a cell-wall constituent of gram-negative bacteria, is a pharmacological ligand of TLR4. In a physiological context, LPS is initially bound in the plasma by LPS binding protein (LBP) and from there transferred to a glycosylphosphatidylinositol (GPI)-anchored molecule (CD14) expressed on the surface of macrophages. An intracellular signaling cascade is subsequently initiated through a receptor complex consisting of TLR4 and the coreceptor MD-2 (Nagai et al., 2002; Akashi et al., 2003; Fig. 3).

TLR signaling requires various intracellular adaptor molecules to activate divergent pathways (Fig. 4). The normal form of LPS (termed "smooth") activates both MyD88/TIRAP and TRIF/TRAM in a CD14-dependent manner, whereas the mutant short-form of LPS in cytosine and guanine bases; UBP, unspecified products of uropathogenic bacteria; CARD, caspase recruitment domain; TIR, Toll/ IL-1R domain; ITAM, immunoreceptor tyrosine-based activation motif; SYK, LYN, FYN (common to all C-type lectins), receptor linked tyrosine kinases; MALT1-Bcl10, mucosa associated lymphoid tissue lymphoma translocation protein-B cell lymphoma 10; Fcy receptor, complement receptor; ds/ss, double stranded/single stranded.

("rough") activates MyD88/TIRAP in a CD14-independent manner (Jiang et al., 2005; Fig. 3).

Activation of TLR2 and TLR4 eventually leads to the downstream activation of NF- $\mathrm{KB}$ and MAP kinases (Akira et al., 2006; O'Neill, 2006; and references therein). $\mathrm{NF}-\kappa \mathrm{B}$ and MAP kinases (see Fig. 4) are master regulators of innate and adaptive immunity as well as cell survival. MyD88 is a vital signaling component for most TLRs (except for TLR3), but the MyD88-TLR bridging molecule TIRAP is dispensable for MyD88 recruitment to TLR5, -7, -8, and -9 (Oshiumi et al., 2003).

TLR4 Myd88-independent signaling is mediated via TRIF using TRAM as a bridging molecule, whereas TLR3 functions through TRIF in a TRAM-independent fashion (Yamamoto et al., 2003). This ultimately leads to IRF-3 and IRF-7 phosphorylation (Hacker et al., 2006). IRF3 and IRF7 are essential for the production of type-1 interferons (IFN), potent antiviral factors (Honda et al., 2005). In addition, IFN-regulatory factor 5 (IRF5), a downstream MyD88-regulated transcription factor, is essential for interleukin (IL)-6, IL-12, and TNF expression (Takaoka et al., 2005).

\section{TLRs on Microglia}

Microglia express most of the known TLR receptor repertoire as well as the adaptor molecules required 


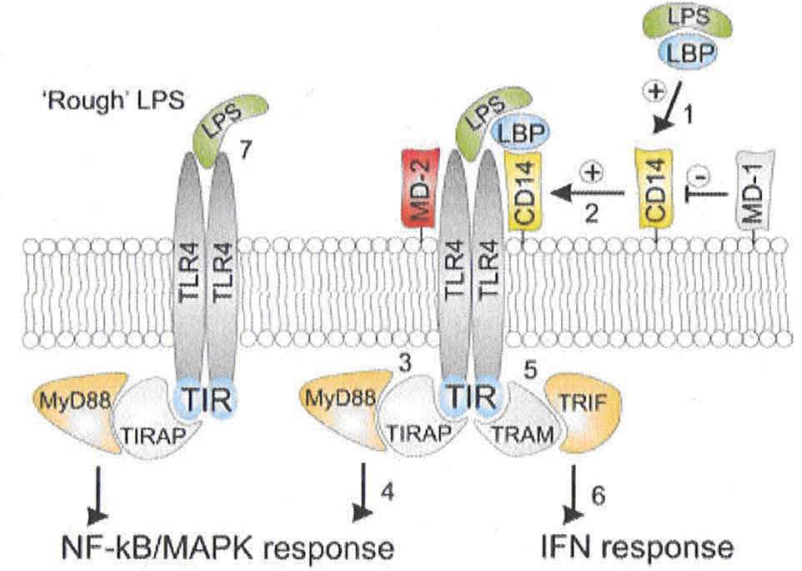

Fig. 3. Example for signaling pathways triggered by gram-negative lipopolysaccharide. 1: LPS binds to LPS-binding protein (LBP) in solution and then to the co-receptor CD14. 2: The complex binds to TLR4, which transmits signals via its cytoplasmic Toll/IL-1R domain (TIR). MD-2 is required as a further coreceptor, whereas MD1 has an inhibitory function. 3: MyD88-adaptor-like $=$ TIR-associated protein (TIRAP/MAL) binds to the TLR-TIR domain and attracts MyD88. 4: MyD88 is a template for attraction of further adaptors and activation of kinases involved in the triggering of NF$\mathrm{\kappa B}$ and MAP kinase cascades. 5: TRIF-related adaptor molecule (TRAM) can also bind directly the TLR-TIR and attract TIR-domain-containing adaptor protein-inducing IFN- $\beta$ (TRIF). 6: This leads to activation of the interferon-response factor 3 (IRF3) and triggering of an interferon response. 7: Rough (=shortened) LPS does not require CD14 to induce the pathway triggered by MyD88, whereas CD14 is necessary for TRIF mediated signaling. [Color figure can be viewed in the online issuc, which is available at www.interscience.wiley.com.]

for downstream TLR signaling (Bsibi et al., 2002; Kielian et al., 2002; Olson and Miller, 2004; Jack et al., 2005; Mishra et al., 2006; Town et al., 2006). Activation of microglia leads to an increased expression of TLRs (Kielian et al., 2002; Olson and Miller, 2004; Jack et al., 2005). These observations are well in line with the expected role of microglia as the main cell type responsible for the primary defense against pathogens entering the brain. Already in a simplified model, using only one artificial ligand, TLR-induced microglia response typically leads to the production of antiviral/bacterial molecules such as TNF, IFN- $\beta$, inducible nitric oxide synthetase, and a multitude of chemokines and pro- and antiinflammatory interleukins, as well as cell proliferation (Olson and Miller, 2004; Lund et al., 2006). Microglia react to a single specific stimulation of either TLR 2 or TLR 4 by lipoteichoic acid (LTA) or LPS, respectively, with the release of proinflammatory cytokines (Lund et al., 2005).

Costimulation of microglia with concentrations of two or more TLR ligands that individually lead to a submaximal stimulus can induce a synergistic response (Ebert et al., 2005). Microglia stimulated with combinations of two different TLR 2 or TLR 4 ligands or combinations of TLR2/TLR4, TLR4/TLR9, and TLR2/
TLR9 ligands release nitric oxide in a synergistic fashion. This observation may be important for an effective host defense, in that individual microorganisms express ligands for multiple TLR receptors. Peptidoglycans (PGN) or LTA from Staphylococcus aureus may activate microglia via TLR2, but TLR2 expression is not essential for recognition of the intact gram-positive bacteria (Kielian et al., 2005b). Deletion of TLR2 led to a decrease in the proinflammatory cytokine production in Staphylococcus aureus-infected CNS tissue. Despite this viability, the number of brain abscesses and the titer of gram-positive bacteria are not affected in TLR2-deficient mice (Kielian et al., 2005a).

\section{Inadvertent Functional Consequences of TLR Activation on Microglia}

In vitro, activation of microglia can result in bystander toxicity of cocultured neurons or oligodendrocytes (Lehnardt et al., 2002, 2003, 2006; Iliev et al., 2004). Intracerebroventricular administration of LPS leads to an increased leukocyte recruitment to the brain via CD14-TLR4 activation in both an MyD88-dependent and an MyD88-independent fashion (H. Zhou et al., 2006). Intracerebral injection of LPS causes rapid and progressive demyelination and neurotoxicity via TLR4 (Lehnardt et al., 2002; Nadeau et al., 2003). LPSinduced neurodegeneration is partially actuated by TNF but is reduced by an endogenous glucocorticoid response in the CNS, which suggests that endogenous mechanisms exist for keeping the innate immune response in check (Nadeau et al., 2003). Peripheral LPS administration, used as a model for sepsis, also induces a strong and chronic proinflammatory CNS response. Despite the delivery of LPS to the periphery, this response requires the expression of TLR4 in the CNS compartment (Chakravarty and Herkenham, 2005). Eventually, such mice develop a delayed, progressive loss of dopaminergic neurons in the substantia nigra, showing that peripheral infections have the capability to induce or augment CNS pathology (Qin et al., 2007). Roles of the TLRdriven innate immune response, beyond pathogen recognition, are suggested by reports that TLR expression on microglia promotes the clearance of $\beta$-amyloid peptide in amyloid precursor protein (APP) transgenic mice and in vitro and that stimulation of TLR9 antagonizes glioma formation (Tahara et al., 2006; El Andaloussi et al., 2006).

\section{TLRs on Astrocytes}

Within the last few years, it has become apparent that nonmyeloid CNS-residing cells express TLRs. Astrocytes express constitutively high levels of TLR3 and the adaptor molecules required for TLR signaling (Farina et al., 2005; Jack et al., 2005). As opposed to microglia, which mainly express TLR 3 in intracellular compartments, astrocytes appear to have both a high intracellular and a high surface expression of TLR3. This possibly reflects the fact that astrocytes are not professio- 


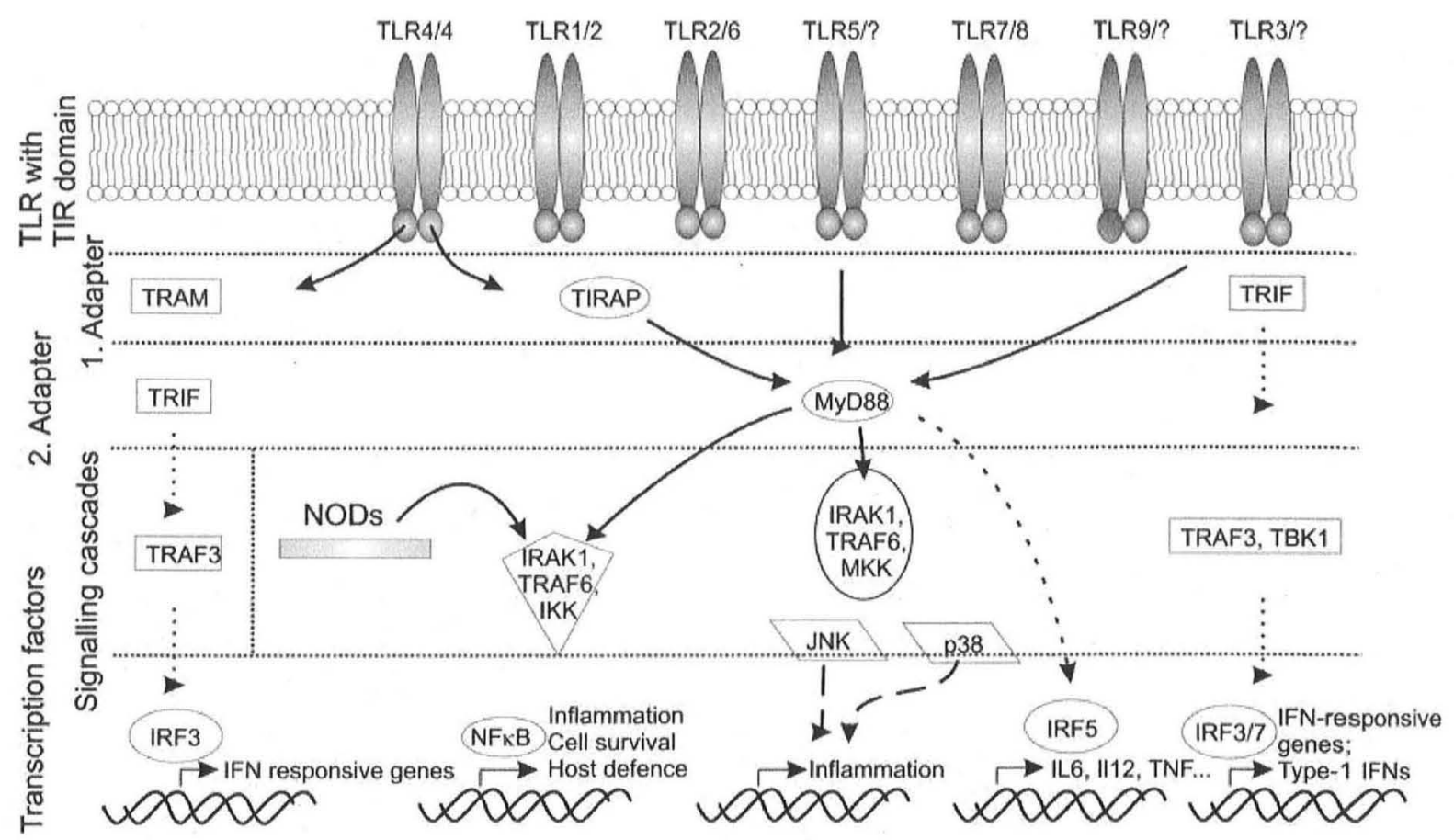

Fig. 4. Inflammatory responses triggered by TLR and NOD. Upon ligand activation, receptors recruit one or several adaptor proteins to their cytoplasmic domain (TIR for TLRs, CARDs for NOD). TRIF and MyD88 are important platforms for the activation of signaling complexes and cascades involving further adaptors, such as TRAF proteins, RICK, IRAK kinases, TANK-binding kinase-1 (TBK1), MAP kinases, and inhibitor of $N F-\kappa B$ kinases (IKK). Ultimately, the signal transduction results in the activation of transcription factors that trigger different panels of inflammatory/host response genes. nal phagocytes and thus would require a high surface expression of TLR3 for an efficient detection of extracellular pathogens. Whether receptor localization has any functional consequences is unknown, but astrocytes respond strongly to TLR3 stimulation in vitro (Carpentier et al., 2005; Farina et al., 2005; Jack et al., 2005; Scumpia et al., 2005; Bsibsi et al., 2006). Stimulation of TLR3 with the dsRNA-mimetic TLR3 ligand polyinosinic-cytidylic acid [poly(I:C)] leads to a proinflammatory response with many similarities to a microglial TLR response. Upon TLR-3 activation, TNF, IFN- $\beta$, inducible nitric oxide synthetase, and a multitude of chemokines and pro- and antiinflammatory ILs as well as IFNregulated antiviral molecules are induced (Scumpia et al., 2005; Bsibsi et al., 2006; So et al., 2006). A similar response is observed when astrocytes are activated by cytokines (John et al., 2005; Falsig et al., 2006). Stimulation of astrocytes with poly(I:C) decreases glutamate uptake by astrocytes, suggesting that an astrocytic response to poly(I:C) may indirectly affect neuronal function and viability (Scumpia et al., 2005). In a different experimental setup, conditioned medium from poly(I:C)treated astrocytes was found to be neuroprotective for cortical brain slice cultures (Bsibsi et al., 2006).

The main role of astrocyte TLRs may lie in viral defense, insofar as poly $(\mathrm{I}: \mathrm{C})$ treatment triggers protection of astrocytes from an infection in vitro. For instance, poly $(\mathrm{I}: \mathrm{C})$ induces the production of an antiviral molecule, Viperin/cig5, that inhibited the replication of a pseudotyped human immunodeficiency virus (HIV) viral particle in astrocytes (Rivieccio et al., 2006). Poly(I:C)induced viperin expression was prevented with IFN- $\beta$ neutralizing antibodies, by inhibiting NF- $\kappa B$ and IRF3, and by a specific viperin knockdown using RNA interference. In all cases, a decrease in viperin expression correlated with an increased viral titter (Rivieccio et al., 2006). Theiler's murine encephalomyelitis virus (TMEV), an experimental model for a virus-mediated demyelinating disease, induces a proinflammatory response in TMEVinfected astrocytes. In astrocytes devoid of TLR3, this response is reduced, but the lack of an inflammatory response does not affect the replication of the virus within astrocytes (So et al., 2006).

Comparing a response of cells infected with a virus and cells treated with purified TLR ligands has certain drawbacks. One of the main concerns associated with using purified TLR ligands as an experimental tool is the purity and specificity of the ligands. Impurities can often be found in LPS preparations (Werts et al., 2001), and many other ligand preparations have in the past often been contaminated with LPS. Even when a ligand preparation is pure, the ligand is not necessarily specific 


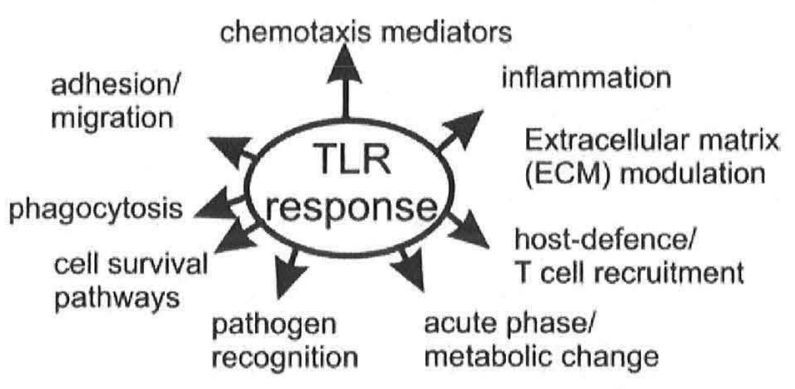

Fig. 5. Downstream events of TLR signaling.

for a given receptor. Poly(I:C), a ligand commonly used to study TLR 3 function, stimulates TLR 3 when applied extracellularly. On the other hand, cytoplasmic delivery of poly (I:C) stimulates the activation of protein kinase R (PKR) and a novel PRR, retinoic acid-inducible gene I (RIG-I; Gunnery and Mathews, 1998; Matsumoto et al., 2002; Yoneyama et al., 2004). This is substantiated by the observation that poly(I:C) induces a robust, although reduced, microglial cytokine response in TLR3- mice compared with wild type (wt; Town et al., 2006).

Discussion of the signaling of TLR in astrocytes is still controversial, because pharmacological tools used to dissect signaling cascades mostly lack absolute specificity, and knockouts may induce compensatory responses allowing for alternative signaling pathways. For instance, poly(I:C) activates PKR in astrocytes, and pharmacological inhibition of PKR was shown to block the poly(I:C)-mediated production of nitric oxide and cytokines. The authors suggested that PKR acted as a downstream effector of a membrane receptor (likely TLR3; Scumpia et al., 2005). Recently, this hypothesis was disputed by showing that PKR $-/-$ astrocytes respond normally to poly $(\mathrm{I}: \mathrm{C})$ treatment, suggesting that PKR does not play a significant role in TLR3 signaling in astrocytes (Carpentier et al., 2007). Also, not all signaling observations correlate with functional consequences. For instance, TMEV activation of astrocytes was shown to be dependent on PKR (not on TLR3). However, no difference in viral replication was detected between wt and PKR-null cells (Carpentier et al., 2007; Fig. 5).

\section{Functional Implication of Astrocyte TLR Receptors}

Little is known about the importance of TLR3 expression on astrocytes in vivo. Intracerebral or peripheral administration of poly(I:C) leads to a strong activation of microglia and astrocytes. These findings prompted the authors to suggest that poly(I:C) activates astrocytes in vivo (Zhang et al., 2005; Town et al., 2006). A pitfall of these studies is that many microgliaderived factors strongly affect the activation state of other CNS residing cells (John et al., 2005). Microglial release of TNF and IL-1 induces a strong production of cytokines and chemokines in astrocytes in vivo, leading to the attraction of microglia and peripheral immune cells to the site of infection/damage (Babcock et al., 2003; Marella et al., 2005). In the previously mentioned in vivo studies, astrocytes were possibly activated indirectly through microglia, indicated by the fact that astrocytes were also strongly activated by LPS, a TLR4 ligand that is relatively microglia specific (Town et al., 2006). Low levels of TLR4 expression on astrocytes in vitro have been described throughout the literature, but in vivo astrocytes do not appear to express TLR4 (Lehnardt et al., 2002; Ma et al., 2006; Mishra et al., 2006).

TLR4 activation by LPS leads to highly variable functional astrocytic responses, possibly because of varying preactivation states of astrocyte cultures, and different states of TLR up-regulation by the preactivation (Lee et al., 1993; Bowman et al., 2003; Esen et al., 2004; Carpentier et al., 2005; Farina et al., 2005; Bsibsi et al., 2006). For instance, rat astrocytes have been reported to respond strongly to LPS but also to be devoid of receptor expression and LPS binding (Chung and Benveniste, 1990; Lehnardt et al., 2002). Human astrocytes have been reported to show an increased mRNA expression in response to LPS stimulation but to a much lesser extend than the response shown after poly(I:C) stimulation (Bsibsi et al., 2006). Concerning the production of polypeptide mediators (e.g., cytokines), astrocytes were found either to be unresponsive to LPS stimulation (Lee et al., 1993) or to release less than $10 \%$ of IL-6 compared with that released by poly(I:C)-stimulated astrocytes (Farina et al., 2005). Also, reports of TLR4-mediated functional responses on murine astrocytes vary enormously. In our hands, we see no effect of LPS stimulation on purified astrocytes from C57BL/6 mice (Falsig et al., 2004). Other groups reported effects on murine astrocytes (Bowman et al., 2003; Esen et al., 2004; Carpentier et al., 2005), but none of the studies showed that the LPS-induced effects are dependent on TLR 4 expression on astrocytes. Furthermore, two of the studies show maximal astrocyte activation at concentrations of 0.01 or $1 \mathrm{ng} / \mathrm{ml}$ of LPS. These concentrations are at least 1,000-fold below what is needed to activate microglia via TLR maximally and thus point to a different mechanism on the astrocytes of these studies (Lee et al., 1993; Bowman et al., 2003; Esen et al., 2004).

The expression pattern of multiple TLR receptors is modulated by proinflammatory stimulation of microglia and astrocytes. Especially TLR2 expression on astrocytes is induced by stimulation with TLR 3 ligands and cytokines in vitro (Bowman et al., 2003; Olson and Miller, 2004; Carpentier et al., 2005; Farina et al., 2005; Jack et al., 2005; Bsibi et al., 2006; Falsig et al., 2006) as well as during a parasitic infection and experimental autoimmune encephalomyelitis in vivo (Zekki et al., 2002; Mishra et al., 2006). Few reports of TLR2 function on astrocytes have been reported, so whether the up-regulation of TLR2 has any functional consequences is at this point unknown. One report suggests that pure astrocyte cultures depleted of microglia using a gliotoxin can respond strongly to TLR2 stimulation induced by Staphylococcus aureus or its cell wall constituent PGN 
(Esen et al., 2004). In addition, soluble CD14 was recently reported to activate astrocytes through TLR2 (Bsibsi et al., 2007). However, the role of TLR2 in astrocyte activation requires further characterization. TLR 5 and TLR9 expression has been reported on astrocytes in vitro and TLR6 and TLR7 in vivo, but functional roles still have to be elucidated (Bsibsi et al., 2002; Mishra et al., 2006).

\section{TLRs on Oligodendrocytes and Neurons}

Not much is known about TLR expression on oligodendrocytes, but mRNA expression for TLR2 and TLR 3 and immunoreactivity for TLR2 have been described (Bsibi et al., 2002; Lehnardt et al., 2006). Recently, TLR3 expression on Purkinje neurons in the cerebellar cortex of post-mortem tissues from patients suffering from chronic or infectious neuropathies was reported (Jackson et al., 2006). In addition, rabies virus with TLR3 stimulation with poly(I:C) was shown to induce the release of IFN- $\beta$ in neurons (a terminally differentiated human cell line; Prehaud et al., 2005). Even more surprising, TLR 8 expression was demonstrated on embryonic and early postnatal neurons in vivo by immunocytochemistry and in situ hybridization, suggesting a role for TLRs in neurodevelopment (Ma et al., 2006). It was shown that TLR 8 is expressed on cortical neurons in vitro and that stimulation with the TLR 8 ligand R848 leads to apoptosis and inhibition of neurite outgrowth independent of $N F-\kappa B$ activation (Ma et al., 2006). It will be exciting to see whether primary cultures of neurons can produce IFN- $\beta$ in response to TLR activation and whether this has any implication for protection against foreign pathogens.

TLR 3 is expressed broadly in inflamed CNS tissue, and so far it appears to be the main, if not the only, TLR receptor expressed at physiologically relevant levels on nonmicroglia cells in the noninjured postnatal CNS. This is consistent with the fact that microglia are the main, but not exclusive, sentinel of the CNS.

\section{Functional Implication of TLRs in Mammalian Host Response}

It is important to note that the contribution of TLR expression to protection against infections in the CNS is currently unclear. Until recently, there was not a single report showing that the loss of TLR expression in the brain parenchyma affects the replication of a pathogen or the survival of the infected host. One report suggests that TLRs [or other poly(I:C) receptors] can mediate a protective CNS response to vesicular stomatitis virus when hyperstimulated with poly(I:C) (De Clercq and De Somer, 1971). Excitingly, it has now been reported that some patients suffering from herpes simplex encephalitis, caused by the neuroinvasion of herpes simplex virus 1 (HSV-1), express a dominant-negative mutation in the TLR3 gene (S.Y. Zhang et al., 2007). This mutation leads to the expression of dominant-nega- tive TLR3, causing a dramatically decreased cellular IFN response to $H S V-1$ and vesicular stomatitis virus. The mutation did not affect the cellular response to a host of other viral infections, showing that the TLR3-mediated natural immunity to HSV-1 and VSV is selective. The authors suggest that the defects in the patients deficient in TLR3 signaling involves an intrinsic defect affecting CNS-residing cells, underscoring the importance of future research into the function of TLR3 in CNS immunity (S.Y. Zhang et al., 2007). The fact that only one report exists regarding the role of TLRs in protection of the CNS from pathogens points to a high degree of functional redundancy between different extracellular and intracellular PRR systems, especially when complex pathogens with multiple PAMPs are to be recognized.

\section{C-Type Lectin Receptors as \\ Membrane-Associated PRRs}

The C-type lectin receptors are a family of carbohydrate-recognizing PRRs. The most well-studied member of the C-type lectins is the mannose receptor (MR; Stahl and Ezekowitz, 1998). The MR is capable of recognizing gram-positive and gram-negative bacteria, parasites, mycobacteria, and yeasts and has been implicated in pathogen uptake and inflammatory responses (Stahl and Ezekowitz, 1998).

$\mathrm{MR}$ protein expression was convincingly shown in primary cultures of human astrocytes, in murine and rat microglia, and in murine astrocytes and neurons in vivo (Marzolo et al., 1999; Burudi and Regnier-Vigouroux, 2001; Zimmer et al., 2003; Liu et al., 2004). However, in other studies, MR expression was found to be restricted to perivascular, meningeal, and choroid plexus macrophages (Fabriek et al., 2005; Galea et al., 2005). The MR binds the highly mannosylated envelope glycoprotein gp120 and serves as a CD4-independent HIV-1 entry receptor on astrocytes (Liu et al., 2004). Astrocyte-HIV-1 interaction induces MMP-2 through the MR, showing that the receptor is functional (LópezHerrera et al., 2005). Surprisingly, MR expression on microglia is down-regulated by proinflammatory stimulation with LPS or IFN- $\gamma$ and up-regulated by stimulation with IL-4 or treatment with dexamethasone (Marzolo et al., 1999; Zimmer et al., 2003). This is inconsistent with a role of MR in an inflammatory setting, and indeed it has been shown in several infection models that MR does not play a crucial role in fungal infections in vivo (Lee et al., 2003). Macrophage uptake of the fungal pathogen Candida albicans was inhibited by $\beta$-glucan and not by $\alpha$-mannan (an MR antagonist), suggesting that fungal uptake was regulated by another $\beta$-glucan-sensitive PRR (Lee et al., 2003). Recently, dectin-1 was identified as this receptor, and it was shown that dectin-deficient mice display severe deficits in their antifungal response (Taylor et al., 2007). Dectin-1 and dectin-2 are C-type lectins important for the recognition and immune response to fungal cell wall constituents such as $\beta$-glucans (Dostert and Tschopp, 2007). How- 
ever, under resting conditions, no dectins are expressed in the brain (Reid et al., 2004; Taylor et al., 2005). Dectin expression is up-regulated by proinflammatory stimuli. Thus, it is possible that the receptors can be upregulated in inflamed CNS tissue, but this is yet to be shown (Taylor et al., 2005).

Dendritic-cell-specific C-type ICAM3 grabbing nonintegrin (DC-SIGN)/CD163 is a C-type lectin PRR that is capable of detecting a multitude of pathogens, including virus, bacteria, fungus, parasites, and tumors (T. Zhou et al., 2006). Both DC-SIGN and dectin have been reported to modulate TLR signaling ( $T$. Zhou et al., 2006; Dostert and Tschopp, 2007). DCSIGN is commonly used as a marker for perivascular macrophages (sometimes described as CNS-residing dendritic cells) in CNS tissue of humans, mice, and monkeys (Kim et al., 2006). The receptor functions as an HIV-1 entry receptor, and the receptor is up-regulated in a few microglia and giant nucleated cells after an HIV-1 infection in vivo (Kim et al., 2006). In addition, DC-SIGN is up-regulated in microglia and foamy macrophages in the brains of mice suffering from experimental autoimmune encephalomyelitis (EAE; Fabriek et al., 2005). Another PRR C-type lectin, Dec 205/CD205, displays a CNS expression pattern similar to that of DCSIGN (Rosicarelli et al., 2005). Few studies have investigated a possible protective role of C-type lectins in CNS infections.

\section{Scavenger Receptors}

Scavenger receptors (SR) are a diverse group of membrane proteins that share the capacity to bind modified low-density lipoproteins. The SRs can be broadly divided into eight different classes $(\mathrm{A}-\mathrm{H})$, and members of several classes have been shown to bind and mediate uptake or respond to a variety of pathogens (Murphy et al., 2005). Class A receptor SR-A mediates phagocytosis of gram-positive and gram-negative bacteria and clearance of endotoxin. SR macrophage receptor with collagenous structure (SR-MARCO) binds bacteria, and SR with C-type lectin (SRCL) mediates uptake of yeasts and gram-positive and gram-negative bacteria (Murphy et al., 2005, and references therein). SR-BI binds LPS, and mutations or polymorphisms of the class $B$ receptor CD36 are associated with protection against cerebral malaria (Omi et al., 2003; Murphy et al., 2005). CD36 is expressed by microglia and mediates a $\beta$-amyloidinduced inflammatory microglia response (El Khoury et al., 2003). CD36-deficient mice are hypersusceptible to Staphylococcus aureus infection, and it was found that $\mathrm{CD} 36$ is a receptor for microbial diacylglycerides that signal via TLR2/6 (Hoebe et al., 2005). In contrast, the response to triacyl lipoproteins requires the presence of TLR1/TLR2 and CD14, but not CD36 (Triantafilou et al., 2006). Other scavenger receptors expressed or induced by inflammatory stimuli on microglia are SRAI/SRAII, SR-MARCO, SR-BI, SRCL, and receptor for advanced glycation endpoints (RAGE; Husemann et al., 2002; Alarcon et al., 2005; Nakamura et al., 2006). Astrocytes express SR-BI, SR-MARCO, and SR-PSOX (CXCL16; Alarcon et al., 2005; Ludwig et al., 2005). SRs appear to mediate inflammation in neurodegenerative diseases (El Khoury et al., 2003), but the exact role of SRs in CNS infections is at present not well characterized.

\section{Structure and Signal Transduction of NOD \\ Proteins as Intracellular Receptors}

The cytoplasmic family of nucleotide-binding oligomerization domain (NOD) proteins comprises important pattern recognition receptors for intracellular immune defense. The NODs are all characterized by three structural domains: 1) a carboxy (C)-terminal domain with multiple leucine-rich repeats (LRR) that recognizes ligands; 2) a central nucleotide binding site (NBS or Nacht domain), which is important for self-oligomerization and possess ATPase activity; and 3) an amino (N)-terminal effector motif, the CARD domain, which is composed of protein-protein interaction cassettes leading to the activation of NF- $\mathrm{KB}$ and/or caspases upon NOD stimulation (Chamaillard et al., 2003a; Martinon and Tschopp, 2005). Two prominent NOD family members, NOD1 (also called CARD4) and NOD2 (also called $C A R D 15)$ trigger activation of $N F-\kappa B$ and subsequent induction of inflammatory mediators. Only recently has an exclusive role of the RICK/RIP2 kinase for coupling of NOD to $N F-\kappa B$ been shown in RICKnull mice, displaying a defective response toward NOD1 and NOD2 agonists (Park et al., 2007).

Both NODs are expressed in the cytosol, where they recognize muropeptides, building blocks of bacterial cell wall PGNs (Chamaillard et al., 2003b; Girardin et al., 2003a,c). NOD1 was initially falsely described as an LPS receptor (Inohara et al., 2001), as a result of muropeptide contamination of an LPS preparation. NOD2 recognizes as minimal active motif the muramyl dipeptide (MDP), which is present in both gram-negative and gram-positive PGN. NOD2, therefore, can be regarded as a broad bacterial sensor (Girardin et al., $2003 \mathrm{~b}$ ). After phagocytosis and treatment by lysosomal proteases, muropeptides may become available to intracellular proteins, but the precise route remains to be defined (Carneiro et al., 2004). Besides NOD, the family of NOD-like intracellular receptors also contains NALP1-3 and other members, but information on their role in neural cells is not yet available. The same applies to RIG-like helicases, another family of cytosolic PRR.

\section{Interplay of NOD and TLR}

Independently of the cell type used, all studies consistently describe a strong synergistic activity of NOD and TLR (for review see Traub et al., 2006). In the case of the TLR4 ligand LPS, NOD stimulation can result in a shift of the dose-response curve by a factor of 1,000 (Traub et al., 2004). It has to be noted that synergistic actions of TLR and NOD ligands already occur with 
low doses of stimuli. Although we do not know in which phase of an infection such synergy can develop, synergistic pathogenic stimuli through different immune receptors might be the rule rather than the exception.

\section{Role of NOD for Neural Cells}

Murine astrocytes as well as murine microglia cells constitutively express functional NOD2 protein, which is up-regulated by stimulation with Borrelia burgdorferi or Neisseria meningitides or by stimulation with TLR ligands (Sterka and Marriott, 2006; Sterka et al., 2006). Furthermore, both astrocytes and microglia express RICK kinase, which is crucial for NOD signaling (Park et al., 2007). Peripheral administration of the NOD2 ligand MDP, as with ligands for TLR3, TLR4, and TLR7/8, leads to proliferation of spinal cord cells in vivo, which is accompanied by activation of microglia cells (Su et al., 2005). MDP stimulation of rat astrocytes alone results in a mild release of nitric oxide, which is significantly increased by stimulation with a ligand of TLR1/2, TLR4, or TLR6 (Guo et al., 2006). The expression of the ionotropic purinergic $\mathrm{P} 2 \mathrm{X} 4$ receptor is regulated in a similar fashion, but the most pronounced effect was observed for MDP-induced TNF release, which was markedly increased in presence of any of the TLR (TLR1-9) ligands investigated. However, the observed effects appeared to be additive rather than synergistic. Whether NOD2 signaling is protective or rather detrimental in an infection scenario and whether there are immune-modulating influences of TLR signaling remain to be determined.

\section{Indirect PRRs}

In addition to the recognition of PAMPs by membrane and intracellular receptors, nature has devised a different recognition strategy. Recognition may occur by soluble proteins, and these proteins, bound to their target, are then recognized by dedicated recognition receptors. Two major systems using this principle are the complement system and the immunoglobulin system. The latter bridges the gap between the innate and the adoptive immune system. Pathogen antigens can be recognized by millions of different antibodies, which are then in turn recognized by a small number of immunoglobulin receptors, which are also found on microglia cells (Peress et al., 1993), the most prominent being the Fc-gamma receptors. The complement system involves several levels of recognition and will therefore be described in more detail.

\section{COMPLEMENT: A UNIQUE INNATE IMMUNE SENSOR FOR DANGER SIGNALS}

The complement system is a central effector arm of the innate immune response consisting of some 30 fluidphase and cell-membrane-associated proteins involved in the recognition and killing of invading pathogens, the clearance of immune complexes and apoptotic cells, and the mediation of inflammation (Frank and Fries, 1991).
More recently, complement has been shown to play a key role in eliciting and modulating adaptive immunity (Carroll, 2004; Hawlisch and Köhl, 2006; X. Zhang et al., 2007). The brain has been shown to synthesize a full and functional complement system (Morgan and Gasque, 1996). The individual components are produced from diverse cell types, such as neurons, astrocytes, and microglia. There is now compelling evidence that complement activation in the brain is a double-edged sword, in that it can exert detrimental or beneficial effects depending on the pathophysiological context (Barnum, 2002; van Beek et al., 2003). More specifically, the complement system has recently emerged as one of the key players in innate immune recognition and clearance of pathogens and toxic entities by resident cells of the human brain (Gasque, 2003; Hauwell et al., 2005).

Complement can be activated through three distinct routes: the classical, alternative, and lectin pathways. Ultimately, activation of the entire complement cascade leads to the formation of the membrane attack complex (MAC), which forms a pore in the phosholipid bilayer of cells. The classical complement pathway is activated primarily by the interaction of $\mathrm{C} 1 \mathrm{q}$ with antibody-antigen complexes, C-reactive protein, and serum amyloid $\mathrm{P}$ protein of the pentraxin family, or ligands exposed on the surface of pathogens (Storrs et al., 1983; Gewurz et al., 1993). Furthermore, C1q binds neuropathologically relevant ligands including $\beta$-amyloid fibrils and apoptotic neurons in vitro (Tenner, 1999; TacnetDelorme et al., 2001; Cole et al., 2006), suggesting an important role for $\mathrm{C} 1 \mathrm{q}$ as sensor molecule that facilitates the clearance of a large variety of danger entities from the CNS (Hauwel et al., 2005).

The initiation of the alternative pathway does not require the presence of immune complexes and leads to the deposition of C3 fragments on target microorganisms. A third activation route involves mannose binding lectin $(\mathrm{MBL})$, a lectin homologous to $\mathrm{C} 1 \mathrm{q}$ that recognizes polysaccharide structures of bacteria, fungi, viruses, and parasites (Turner, 2003) as well as apoptotic cells (Ogden et al., 2001) and triggers the complement pathway independently of both the classical and the alternative activation pathways. Activation of the three complement pathways generates the fragments C $3 b$ and finally iC3b, two opsonins that flag the target cell to promote phagocytosis.

\section{Complement Receptors Involved in Phagocytosis}

The complement receptor CR3 (CD11b/CD18) recognizes $\mathrm{C} 3 \mathrm{~b}$ and $\mathrm{iC} 3 \mathrm{~b}$ and is expressed by microglia (Perry et al., 1985; Akiyama and McGeer, 1990). Additionally, CR3 directly recognizes pathogen surface molecules such as LPS and beta-glucan (Ross, 2002) and mediates the elimination of degenerated myelin by macrophages and microglia (Rotshenker, 2003). The complement receptor CR1 (CD35) also binds to C1q, C3b, iC 3b, and MBL and, as such, has been implicated in phagocytic and complement regulatory activities (Krych-Goldberg 
and Atkinson, 2001), whereas the complement receptors $\mathrm{C} 3 \mathrm{aR}$ and $\mathrm{C} 5 \mathrm{aR}$ have different immunomodulatory functions.

\section{Regulation of Complement Activation}

To protect "self" cells against bystander lysis, host cells express a battery of secreted or membrane-bound complement inhibitors. Membrane-associated complement inhibitors include membrane cofactor protein $(\mathrm{MCP}=\mathrm{CD} 46)$, decay-accelerating factor $(\mathrm{DAF}=$ CD55), and CD59. Notably, an inhibitor of complement activation termed "complement receptor-related protein y" (Crry) is expressed on rodent, but not on human, cell membranes. Crry is broadly distributed and is a functional and structural analog of human DAF and MCP. Wyss-Coray and colleagues (2002) demonstrated that complement activation reduces the accumulation or promotes the clearance of $\beta$-amyloid plaques in transgenic mice overexpressing the human amyloid precurser protein (hAPP). Transgenic hAPP mice coexpressing a soluble form of the complement inhibitor Crry under the glial fibrillary acidic protein promoter displayed increased $\beta$-amyloid deposits and more prominent neurodegeneration than what is found in age-matched mice (Wyss-Coray et al., 2002).

\section{Complement and CNS Bacterial Infection}

Complement protein levels have been found to be elevated in the cerebrospinal fluid of patients with bacterial meningitis (Stahel et al., 1997). Furthermore, deficiencies in, e.g., the alternative pathway seem to increase susceptibility to meningococcal disease, underscoring the importance of the complement-dependent defense against this particular pathogen (Speth et al., 2002). In patients with bacterial meningitis, recovery was correlated with higher levels of C4 and C3 in the cerebrospinal fluid (Zwahlen et al., 1982). The complement system also limits pneumococcal outgrowth in the CNS. Rabbits treated with cobra venom factor to deplete complement were found to be more susceptible to intracisternal inoculation of S. pneumoniae (Tuomanen et al., 1986). More recently, Rupprecht and colleagues (2007), using mice deficient in either $\mathrm{C} 1 \mathrm{q}$ or $\mathrm{C} 3$, showed that complement is a central regulator of the innate immune response to pneumococcal CNS infection. However, given the multiple roles of the complement system, it has been difficult so far to identify their specific roles in the pathogenesis of CNS bacterial infection. Indeed, besides its role in the recognition and clearance of invading bacterial pathogens, the complement system has been shown to play a major role in the inflammatory response within the intrathecal compartment, thus possibly contributing to brain damage caused by an excessive inflammatory response (Stahel and Barnum, 1997).

\section{Complement and Virus-Induced Encephalitis}

The cerebral complement system has been hypothesized to contribute to neurodegeneration in the pathogenesis of acquired immune deficiency syndrome (AIDS)-associated neurological disorders (Speth et al., 2002). Complement synthesis by astrocytes is dramatically increased after infection with HIV. This observation is in line with data showing elevated complement in cerebrospinal fluid of patients with HIV infection (Jongen et al., 2000). Complement activation may thus provide first-line brain immune defense by triggering lysis of virions and infected cells (Speth et al., 2007). In turn, HIV, either opsonized by complement or immunocomplexed, may bind to complement receptors expressed on the surface of astrocytes and microglia, thus favoring their infection, as observed in the periphery (Montefiori et al., 1996). Additionally, viruses can enter the brain by interacting with specific complement receptors expressed by neurons and glial cells: DAF for enteroviruses and echoviruses, CD21 for Epstein-Barr virus, emphasizing the critical role of the complement system in virus-induced encephalitis (Hauwell et al., 2005).

\section{SUMMARY AND OUTLOOK}

Many receptors associated with the detection of pathogens and the initiation of an immune response in the periphery are also expressed within the brain. The recent observation that PRR receptors are expressed not only by microglia but also by other CNS-residing cells suggests a role of these cells in pathogen detection. It will be exciting to find out whether these cells play a major role in initiating a protective CNS innate immune response and which PRRs contribute to it. In view of the immune-dampened status of the brain, it will also be interesting to see whether PRRs couple to the same signal transduction and response machinery as in the periphery and how far the inflammatory response correlates with the elimination of pathogens.

\section{REFERENCES}

Akashi S, Saitoh S, Wakabayashi Y, Kikuchi T, Takamura N, Nagai Y, Kusumoto Y, Fukase K, Kusumoto S, Adachi Y, Kosugi A, Miyake K. 2003. Lipopolysaccharide interaction with cell surface Toll-like receptor 4-MD-2: higher affinity than that with MD-2 or CD14. J Exp Med 198:1035-1042.

Akira S, Uematsu S, Takeuchi O. 2006. Pathogen recognition and innate immunity. Cell 124:783-801.

Akiyama H, McGeer PL. 1990. Brain microglia constitutively express beta-2 integrins. J Neuroimmunol 30:81-93.

Alarcon R, Fuenzalida C, Santibanez M, von Bernhardi R. 2005. Expression of scavenger receptors in glial cells. Comparing the adhesion of astrocytes and microglia from neonatal rats to surface-bound betaamyloid. J Biol Chem 280:30406-30415.

Babcock AA, Kuziel WA, Rivest S, Owens T. 2003. Chemokine expression by glial cells directs leukocytes to sites of axonal injury in the CNS. J Neurosci 23:7922-7930.

Barnum SR. 2002. Complement in central nervous system inflammation. Immunol Res 26:7-13.

Becher B, Bechmann I, Greter M. 2006. Antigen presentation in autoimmunity and CNS inflammation: how $\mathrm{T}$ lymphocytes recognize the brain. J Mol Med 84:532-543.

Bechmann I, Galea I, Perry VH. 2007. What is the blood-brain barrier (not)? Trends Immunol 28:5-11. 
Bowman CC, Rasley A, Tranguch SL, Marriott I. 2003. Cultured astrocytes express toll-like receptors for bacterial products. Glia 43:281-291.

Bsibsi M, Ravid R, Gveric D, van Noort JM. 2002. Broad expression of Toll-like receptors in the human central nervous system. J Neuropathol Exp Neurol 61:1013-1021.

Bsibsi M, Persoon-Deen C, Verwer RW, Meeuwsen S, Ravid R, Van Noort JM. 2006. Toll-like receptor 3 on adult human astrocytes triggers production of neuroprotective mediators. Glia 53:688-695.

Bsibsi M, Bajramovic JJ, Van Duijvenvoorden E, Persoon C, Ravid R, Van Noort JM, Vogt MH. 2007. Identification of soluble CD14 as an endogenous agonist for Toll-like receptor 2 on human astrocytes by genome-scale functional screening of glial cell derived proteins. Glia 55:473-482.

Burudi EM, Regnier-Vigouroux A. 2001. Regional and cellular expression of the mannose receptor in the post-natal developing mouse brain. Cell Tissue Res 303:307-317.

Carneiro LA, Travassos LH, Philpott DJ. 2004. Innate immune recognition of microbes through Nod1 and Nod2: implications for disease. Microbes Infect 6:609-616.

Carpentier PA, Begolka WS, Olson JK, Elhofy A, Karpus WJ, Miller SD. 2005. Differential activation of astrocytes by innate and adaptive immune stimuli. Glia 49:360-374.

Carpentier PA, Williams BR, Miller SD. 2007. Distinct roles of protein kinase $\mathrm{R}$ and toll-like receptor 3 in the activation of astrocytes by viral stimuli. Glia 55:239-252.

Carroll MC. 2004. The complement system in regulation of adaptive immunity. Nat Immunol 5:981-986.

Chakravarty S, Herkenham M. 2005. Toll-like receptor 4 on nonhematopoietic cells sustains CNS inflammation during endotoxemia, independent of systemic cytokines. J Neurosci 25:1788-1796.

Chamaillard M, Girardin SE, Viala J, Philpott DJ. 2003a. Nods, Nalps and Naip: intracellular regulators of bacterial-induced inflammation. Cell Microbiol 5:581-592.

Chamaillard M, Hashimoto M, Horie Y, Masumoto J, Qiu S, Saab L, Ogura Y, Kawasaki A, Fukase K, Kusumoto S, Valvano MA, Foster SJ, Mak TW, Nunez G, Inohara N. 2003b. An essential role for NOD1 in host recognition of bacterial peptidoglycan containing diaminopimelic acid. Nat Immunol 4:702-707.

Chung IY, Benveniste EN. 1990. Tumor necrosis factor-alpha production by astrocytes. Induction by lipopolysaccharide, IFN-gamma, and IL-1 beta. J Immunol 144:2999-3007.

Cole DS, Hughes TR, Gasque P, Morgan BP. 2006. Complement regulator loss on apoptotic neuronal cells causes increased complement activation and promotes both phagocytosis and cell lysis. Mol Immunol 43:1953-1964.

De Clercq E, De Somer P. 1971. Comparative study of the efficacy of different forms of interferon therapy in the treatment of mice challenged intranassaly with vesicular stomatitis virus (VSV). Proc Soc Exp Biol Med 138:301-307.

Dostert C, Tschopp J. 2007. DEteCTINg fungal pathogens. Nat Immunol 8:17-18.

Ebert S, Gerber J, Bader S, Mühlhauser F, Brechtel K, Mitchell TJ, Nau R. 2005. Dose-dependent activation of microglial cells by Toll-like receptor agonists alone and in combination. J Neuroimmunol 159:87-96.

El Andaloussi A, Sonabend AM, Han Y, Lesniak MS. 2006. Stimulation of TLR9 with CpG ODN enhances apoptosis of glioma and prolongs the survival of mice with experimental brain tumors. Glia 54:526-535.

El Khoury JB, Moore KJ, Means TK, Leung J, Terada K, Toft M, Freeman MW, Luster AD. 2003. CD36 mediates the innate host response to beta-amyloid. J Exp Med 197:1657-1666.

Elward K, Gasque P. 2003. "Eat me" and "don't eat me" signals govern the innate immune response and tissue repair in the CNS: emphasis on the critical role of the complement system. Mol Immunol 40:85-94.
Esen N, Tanga FY, DeLeo JA, Kielian T. 2004. Toll-like receptor 2 (TLR2) mediates astrocyte activation in response to the gram-positive bacterium Staphylococcus aureus. J Neurochem 88:746-758.

Fabrick BO, Van Haastert ES, Galea I, Polfliet MM, Dopp ED, Van Den Heuvel MM, Van Den Berg TK, De Groot CJ, Van Der Valk P, Dijkstra CD. 2005. CD163-positive perivascular macrophages in the human CNS express molecules for antigen recognition and presentation. Glia 51:297-305.

Falsig J, Latta M, Leist M. 2004. Defined inflammatory states in astrocyte cultures: correlation with susceptibility towards CD95-driven apoptosis J Neurochem 88:181-193.

Falsig J, Porzgen P, Lund S, Schrattenholz A, Leist M. 2006. The inflammatory transcriptome of reactive murine astrocytes and implications for their innate immune function. J Neurochem 96:893-907.

Farina C, Krumbholz M, Giese T, Hartmann G, Aloisi F, Meinl E. 2005. Preferential expression and function of Toll-like receptor 3 in human astrocytes. J Neuroimmunol 159:12-19.

Frank MM, Fries LF. 1991. The role of complement in inflammation and phagocytosis. Immunol Today 12:322-326

Galea I, Palin K, Newman TA, Van Rooijen N, Perry VH, Boche D. 2005. Mannose receptor expression specifically reveals perivascular macrophages in normal, injured, and diseased mouse brain. Glia 49:375384

Gewurz H, Ying SC, Jiang H, Lint TF. 1993. Nonimmune activation of the classical complement pathway. Behring Inst Mitt 93:138-147.

Girardin SE, Boneca IG, Viala J, Chamaillard M, Labigne A, Thomas G, Philpott DJ, Sansonetti PJ. 2003a. Nod2 is a general sensor of peptidoglycan through muramyl dipeptide (MDP) detection. J Biol Chem 278:8869-8872

Girardin SE, Travassos LH, Herve M, Blanot D, Boneca IG, Philpott DJ, Sansonetti PJ, Mengin-Lecreulx D. 2003b. Peptidoglycan molecular requirements allowing detection by Nod1 and Nod2. J Biol Chem 278:41702-41708

Girardin SE, Boneca IG, Carneiro LA, Antignac A, Jehanno M, Viala J, Tedin $K$, Taha MK, Labigne A, Zathringer U, Coyle AJ, DiStefano PS, Bertin J, Sansonetti PJ, Philpott DJ. 2003c. Nod1 detects a unique muropeptide from gram-negative bacterial peptidoglycan. Science 300:1584-1587.

Gunnery S, Mathews MB. 1998. RNA binding and modulation of PKR activity. Methods 15:189-198.

Guo LH, Guo KT, Wendel HP, Schluesener HJ. 2006. Combinations of TLR and NOD2 ligands stimulate rat microglial P2X4R expression. Biochem Biophys Res Commun 349:1156-1162.

Hacker H, Redecke V, Blagoev B, Kratchmarova I, Hsu LC, Wang GG, Kamps MP, Raz E, Wagner H, Hacker G, Mann M, Karin M. 2006. Specificity in Toll-like receptor signalling through distinct effector functions of TRAF3 and TRAF6. Nature 439:204-207.

Hauwel M, Furon E, Canova C, Griffiths M, Neal J, Gasque P. 2005 Innate (inherent) control of brain infection, brain inflammation and brain repair: the role of microglia, astrocytes, "protective" glial stem cells and stromal ependymal cells. Brain Res Rev 48:220-233.

Hawlisch H, Köhl J. 2006. Complement and Toll-like receptors: key regulators of adaptive immune responses. Mol Immunol 43:13-21.

Heppner FL, Greter M, Marino D, Falsig J, Raivich G, Hovelmeyer N, Waisman A, Rulicke T, Prinz M, Priller J, Becher B, Aguzzi A. 2005. Experimental autoimmune encephalomyelitis repressed by microglial paralysis. Nat Med 11:146-152.

Hoebe K, Georgel P, Rutschmann S, Du X, Mudd S, Crozat K, Sovath S, Shamel L, Hartung T, Zahringer U, Beutler B. 2005. CD36 is a sensor of diacylglycerides. Nature 433:523-527.

Honda K, Yanai H, Negishi H, Asagiri M, Sato M, Mizutani T, Shimada N, Ohba Y, Takaoka A, Yoshida N, Taniguchi T. 2005. IRF-7 is the master regulator of type-I interferon-dependent immune responses. $\mathrm{Na}$ ture 434:772-777. 
Husemann J, Loike JD, Anankov R, Febbraio M, Silverstein SC. 2002. Scavenger receptors in neurobiology and neuropathology: their role on microglia and other cells of the nervous system. Glia 40:195-205.

Iliev AJ, Stringaris AK, Nau R, Neumann H. 2004. Neuronal injury mediated via stimulation of microglial toll-like receptor-9 (TLR9). FASEB J 18:412-414.

Inohara N, Ogura Y, Chen FF, Muto A, Nunez G. 2001. Human Nod1 confers responsiveness to bacterial lipopolysaccharides. J Biol Chem 276:2551-2554.

Jack CS, Arbour N, Manusow J, Montgrain V, Blain M, McCrea E, Shapiro A, Antel JP. 2005. TLR signaling tailors innate immune responses in human microglia and astrocytes. J Immunol 175:4320-4330.

Jackson AC, Rossiter JP, Lafon M. 2006. Expression of Toll-like receptor 3 in the human cerebellar cortex in rabies, herpes simplex encephalitis, and other neurological diseases. J Neurovirol 12:229-234.

Jiang Z, Georgel P, Du X, Shamel L, Sovath S, Mudd S, Huber M, Kalis C, Keck S, Galanos C, Freudenberg M, Beutler B. 2005. CD14 is required for MyD88-independent LPS signaling. Nat Immunol 6:565570.

John GR, Lee SC, Song X, Rivieccio M, Brosnan CF. 2005. IL-1-regulated responses in astrocytes: relevance to injury and recovery. Glia 49:161-176.

Jongen PJ, Doesburg WH, Ibrahim-Stappers JL, Lemmens WA, Hommes OR, Lamers KJ. 2000. Cerebrospinal fluid C3 and C4 indexes in immunological disorders of the central nervous system. Acta Neurol. Scand. 2000 Feb; 101:116-121.

Kielian T, Mayes P, Kielian M. 2002. Characterization of microglial responses to Staphylococcus aureus: effects on cytokine, costimulatory molecule, and Toll-like receptor expression. J Neuroimmunol 130:8699.

Kielian T, Haney A, Mayes PM, Garg S, Esen N. 2005a. Toll-like receptor 2 modulates the proinflammatory milieu in Staphylococcus aureusinduced brain abscess. Infect Immun 73:7428-7435.

Kiclian T, Esen N, Bcarden ED. 2005b. Toll-like receptor 2 (TLR2) is pivotal for recognition of $\mathrm{S}$. aureus peptidoglycan but not intact bacteria by microglia. Glia 49:567-576.

Kim WK, Alvarez X, Fisher J, Bronfin B, Westmoreland S, McLaurin J, Williams K. 2006. CD163 identifies perivascular macrophages in normal and viral encephalitic brains and potential precursors to perivascular macrophages in blood. Am J Pathol 168:822-834.

Krych-Goldberg M, Atkinson JP. 2001. Structure-function relationships of complement receptor type 1. Immunol Rev 180:112-122.

Lee SC, Liu W, Dickson DW, Brosnan CF, Berman JW. 1993. Cytokine production by human fetal microglia and astrocytes. Differential induction by lipopolysaccharide and IL-1 beta. J Immunol 150:2659-2667.

Lee SJ, Zheng NY, Clavijo M, Nussenzweig MC. 2003. Normal host defense during systemic candidiasis in mannose receptor-deficient mice. Infect Immun 71:437-445.

Lehnardt S, Lachance C, Patrizi S, Lefebvre S, Follett PL, Jensen FE, Rosenberg PA, Volpe JJ, Vartanian T. 2002. The toll-like receptor TLR4 is necessary for lipopolysaccharide-induced oligodendrocyte injury in the CNS. J Neurosci 22:2478-2486.

Lehnardt S, Massillon L, Follett P, Jensen FE, Ratan R, Rosenberg PA, Volpe JJ, Vartanian T. 2003. Activation of innate immunity in the CNS triggers neurodegeneration through a Toll-like receptor 4-dependent pathway. Proc Natl Acad Sci U S A 100:8514-8519.

Lehnardt S, Henneke P, Lien E, Kasper DL, Volpe JJ, Bechmann I, Nitsch R, Weber JR, Golenbock DT, Vartanian T. 2006. A mechanism for neurodegeneration induced by group B streptococci through activation of the TLR2/MyD88 pathway in microglia. J Immunol 177:583-592.

Lemaitre B, Nicolas E, Michaut L, Reichhart JM, Hoffmann JA. 1996 The dorsoventral regulatory gene cassette spatzle/Toll/cactus controls the potent antifungal response in Drosophila adults. Cell 86:973-983.
Liu Y, Liu H, Kim BO, Gattone VH, Li J, Nath A, Blum J, He JJ. 2004. CD4-independent infection of astrocytes by human immunodeficiency virus type 1: requirement for the human mannose receptor. J Virol 78:4120-4133.

López-Herrera A, Liu Y, Rugeles MT, He JJ. 2005. HIV-1 interaction with human mannose receptor (hMR) induces production of matrix metalloproteinase 2 (MMP-2) through hMR-mediated intracellular signaling in astrocytes. Biochim Biophys Acta 1741:55-64.

Ludwig A, Schulte A, Schnack C, Hundhausen C, Reiss K, Brodway N, Held-Feindt J, Mentlein R. 2005. Enhanced expression and shedding of the transmembrane chemokine CXCL16 by reactive astrocytes and glioma cells. J Neurochem 93:1293-1303.

Lund S, Porzgen P, Mortensen AL, Hasseldam H, Bozyczko-Coyne D, Morath S, Hartung T, Bianchi M, Ghezzi P, Bsibsi M, Dijkstra S, Leist M. 2005. Inhibition of microglial inflammation by the MLK inhibitor CEP-1347. J Neurochem 92:1439-1451.

Lund S, Christensen KV, Hedtjarn M, Mortensen AL, Hagberg H, Falsig J, Hasseldam H, Schrattenholz A, Porzgen P, Leist M. 2006. The dynamics of the LPS triggered inflammatory response of murine microglia under different culture and in vivo conditions. J Neuroimmunol 180:71-87.

Ma Y, Li J, Chiu I, Wang Y, Sloane JA, Lu J, Kosaras B, Sidman RL, Volpe JJ, Vartanian T. 2006. Toll-like receptor 8 functions as a negative regulator of neurite outgrowth and inducer of neuronal apoptosis. J Cell Biol 175:209-215.

Marella M, Gaggioli C, Batoz M, Deckert M, Tartare-Deckert S, Chabry J. 2005. Pathological prion protein exposure switches on neuronal mitogen-activated protein kinase pathway resulting in microglia recruitment. J Biol Chem 280:1529-1534.

Martinon F, Tschopp J. 2005. NLRs join TLRs as innate sensors of pathogens. Trends Immunol 26:447-454.

Marzolo MP, von Bernhardi R, Inestrosa NC. 1999. Mannose receptor is present in a functional state in rat microglial cells. J Neurosci Res 58:387-395

Matsumoto M, Kikkawa S, Kohase M, Miyake K, Seya T. 2002. Establishment of a monoclonal antibody against human Toll-like receptor 3 that blocks double-stranded RNA-mediated signaling. Biochem Biophys Res Commun 293:1364-1369.

Medawar PB. 1948. Immunity to homologous grafted skin. III. The fate of skin homografts transplanted to the brain, to subcutaneous tissue, and to the anterior chamber of the eye. Br J Exp Pathol 29:58-69

Medzhitov R, Janeway CA Jr. 2002. Decoding the patterns of self and nonself by the innate immune system. Science 296:298-300.

Meylan E, Tschopp J, Karin M. 2006. Intracellular pattern recognition receptors in the host response. Nature 442:39-44.

Mishra BB, Mishra PK, Teale JM. 2006. Expression and distribution of Toll-like receptors in the brain during murine neurocysticercosis. J Neuroimmunol 181:46-56.

Mizel SB, Honko AN, Moors MA, Smith PS, West AP. 2003. Induction of macrophage nitric oxide production by gram-negative flagellin involves signaling via heteromeric Toll-like receptor 5/Toll-like receptor 4 complexes. J Immunol 170:6217-6223.

Montefiori DC, Pantaleo G, Fink LM, Zhou JT, Zhou JY, Bilska M, Miralles GD, Fauci AS. 1996. Neutralizing and infection-enhancing antibody responses to human immunodeficiency virus type 1 in longterm nonprogressors. J Infect Dis 173:60-67.

Morgan BP, Gasque P. 1996. Expression of complement in the brain: role in health and disease. Immunol Today 17:461-466.

Murphy JE, Tedbury PR, Homer-Vanniasinkam S, Walker JH, Ponnambalam S. 2005. Biochemistry and cell biology of mammalian scavenger receptors. Atherosclerosis 182:1-15.

Nadeau S, Rivest S. 2003. Glucocorticoids play a fundamental role in protecting the brain during innate immune response. I Neurosci 23:5536-5544 
Nagai $Y$, Akashi S, Nagafuku $M$, Ogata $M$, Iwakura $Y$, Akira S, Kitamura T, Kosugi A, Kimoto M, Miyake K. 2002. Essential role of MD2 in LPS responsiveness and TLR4 distribution. Nat Immunol 3:667672 .

Nakamura K, Ohya W, Funakoshi H, Sakaguchi G, Kato A, Takeda M, Kudo T, Nakamura T. 2006. Possible role of scavenger receptor SRCL in the clearance of amyloid-beta in Alzheimer's disease. J Neurosci Res 84:874-890.

Ogden CA, deCathelineau A, Hoffmann PR, Bratton D, Ghebrehiwet B, Fadok VA, Henson PM. 2001. Clq and mannose binding lectin engagement of cell surface calreticulin and CD91 initiates macropinocytosis and uptake of apoptotic cells. J Exp Med 194:781-795.

Olson JK, Miller SD. 2004. Microglia initiate central nervous system innate and adaptive immune responses through multiple TLRs. J Immunol 173:3916-3924.

Omi K, Ohashi J, Patarapotikul J, Hananantachai H, Naka I, Looareesuwan S, Tokunaga K. 2003. CD36 polymorphism is associated with protection from cerebral malaria. Am J Hum Genet 72:364-374.

O'Neill LA. 2006. Targeting signal transduction as a strategy to treat inflammatory diseases. Nat Rev Drug Discov 51:549-563.

Oshiumi H, Matsumoto M, Funami K, Akazawa T, Seya T. 2003. TICAM-1, an adaptor molecule that participates in Toll-like receptor 3-mediated interferon-beta induction. Nat Immunol 4:161-167.

Owens T, Wekerle H, Antel J. 2001. Genetic models for CNS inflammation. Nat Med 7:161-166.

Ozinsky A, Underhill DM, Fontenot JD, Hajjar AM, Smith KD, Wilson CB, Schroeder L, Aderem A. 2000. The repertoire for pattern recognition of pathogens by the innate immune system is defined by cooperation between toll-like receptors. Proc Natl Acad Sci U S A 97:1376613771.

Park JH, Kim YG, McDonald C, Kanneganti TD, Hasegawa M, BodyMalapel M, Inohara N, Nunez G. 2007. RICK/RIP2 mediates innate immune responses induced through Nod1 and Nod2 but not TLRs. J Immunol 178:2380-2386.

Peress NS, Fleit HB, Perillo E, Kuljis R, Pezzullo C. 1993. Identification of Fc gamma RI, II and III on normal human brain ramified microglia and on microglia in senile plaques in Alzheimer's disease. J Neuroimmunol 48:71-79.

Perry VH, Hume DA, Gordon S. 1985. Immunohistochemical localization of macrophages and microglia in the adult and developing mouse brain. Neuroscience 15:313-326.

Prehaud C, Megret F, Lafage M, Lafon M. 2005. Virus infection switches TLR-3-positive human neurons to become strong producers of beta interferon. J Virol 79:12893-12904.

Priller J, Prinz M, Heikenwalder M, Zeller N, Schwarz P, Heppner FL, Aguzzi A. 2006. Early and rapid engraftment of bone marrow-derived microglia in scrapic. J Neurosci 26:11753-11762.

Qin L, Wu X, Block ML, Liu Y, Breese GR, Hong JS, Knapp DJ, Crews FT. 2007. Systemic LPS causes chronic neuroinflammation and progressive neurodegeneration. Glia 55:453-462.

Reid DM, Montoya M, Taylor PR, Borrow P, Gordon S, Brown GD, Wong SY. 2004. Expression of the beta-glucan receptor, Dectin-1, on murine leukocytes in situ correlates with its function in pathogen recognition and reveals potential roles in leukocyte interactions. J Leuk Biol 76:86-94.

Rivieccio MA, Suh HS, Zhao Y, Zhao ML, Chin KC, Lee SC, Brosnan CF. 2006. TLR3 ligation activates an antiviral response in human fetal astrocytes: a role for viperin/cig5. J Immunol 177:4735-4741.

Rolls A, Shechter R, London A, Ziv Y, Ronen A, Levy R, Schwartz M. 2007. Toll-like receptors modulate adult hippocampal neurogenesis. Nat Cell Biol 9:1081-1088.

Rosicarelli B, Serafini B, Sbriccoli M, Lu M, Cardone F, Pocchiari M, Aloisi F. 2005. Migration of dendritic cells into the brain in a mouse model of prion disease. J Neuroimmunol 165:114-120.
Ross GD. 2002. Role of the lectin domain of Mac-1/CR3 (CD11b/ CD18) in regulating intercellular adhesion. Immunol Res 25:219-227.

Rotshenker S. 2003. Microglia and macrophage activation and the regulation of complement-receptor-3 (CR3/MAC-1)-mediated myelin phagocytosis in injury and disease. J Mol Neurosci 21:65-72.

Rupprecht TA, Angele B, Klein M, Heesemann J, Pfister HW, Botto M, Koedel U. 2007. Complement C1q and C3 are critical for the innate immune response to Streptococcus pncumoniae in the central nervous system. J Immunol 178:1861-1869.

Scumpia PO, Kelly KM, Reeves WH, Stevens BR. 2005. Doublestranded RNA signals antiviral and inflammatory programs and dysfunctional glutamate transport in TLR3-expressing astrocytes. Glia 52:153162.

Simard AR, Soulet D, Gowing G, Julien JP, Rivest S. 2006. Bone marrow-derived microglia play a critical role in restricting senile plaque formation in Alzheimer's disease. Neuron 49:489-502.

So EY, Kang MH, Kim BS. 2006. Induction of chemokine and cytokine genes in astrocytes following infection with Theiler's murine encephalomyelitis virus is mediated by the Toll-like receptor 3. Glia 53:858867

Speth C, Dierich MP, Gasque P. 2002. Neuroinvasion by pathogens: a key role of the complement system. Mol Immunol 38:669-679.

Speth C, Rambach G, Hagleitner M, Konstanzer K, Höllmüller I, Dierich MP, Mohsenipour I, Maier H. 2007. Immune response to retroviral infections of the brain. Front Biosci 112:1508-1519.

Stahel PF, Barnum SR. 1997. Bacterial meningitis: complement gene expression in the central nervous system. Immunopharmacology 38:6572.

Stahel PF, Nadal D, Pfister HW, Paradisis PM, Barnum SR. 1997. Complement $\mathrm{C} 3$ and factor $\mathrm{B}$ cerebrospinal fluid concentrations in bacterial and aseptic meningitis. Lancet 349:1886-1887.

Stahl PD, Ezekowitz RA. 1998. The mannose receptor is a pattern recognition receptor involved in host defense. Curr Opin Immunol 10:50-55.

Sterka D Jr, Marriott I. 2006. Characterization of nucleotide-binding oligomerization domain (NOD) protein expression in primary murine microglia. J Neuroimmunol 179:65-75.

Sterka D Jr, Rati DM, Marriott I. 2006. Functional expression of NOD2, a novel pattern recognition receptor for bacterial motifs, in primary murine astrocytes. Glia 53:322-330.

Storrs SB, Kolb WP, Olson MS. 1983. C1q binding and C1 activation by various isolated cellular membranes. J Immunol 131:416-22.

Su Y, Zhang Z, Trautmann K, Xu S, Schluesener HJ. 2005. TLR and NOD2 ligands induce cell proliferation in the rat intact spinal cord J Neuropathol Exp Neurol 64:991-997.

Tacnet-Delorme P, Chevallier S, Arlaud GJ. 2001. Beta-amyloid fibrils activate the $\mathrm{C} 1$ complex of complement under physiological conditions: evidence for a binding site for A beta on the C1q globular regions. J Immunol 167:6374-6381

Tahara K, Kim HD, Jin JJ, Maxwell JA, Li L, Fukuchi KI. 2006. Role of toll-like receptor signalling in $A \beta$ uptake and clearance. Brain 129:3006-3019.

Takaoka A, Yanai H, Kondo S, Duncan G, Negishi H, Mizutani T, Kano S, Honda K, Ohba Y, Mak TW, Taniguchi T. 2005. Integral role of IRF-5 in the gene induction programme activated by Toll-like receptors. Nature 434:243-249.

Tang SC, Arumugam TV, Xu X, Cheng A, Mughal MR, Jo DG, Lathia JD, Siler DA, Chigurupati S, Ouyang X, Magnus T, Camandola S, Mattson MP. 2007. Pivotal role for neuronal Toll-like receptors in ischemic brain injury and functional deficits. Proc Natl Acad Sci U S A 104:13798-13803.

Taylor PR, Reid DM, Heinsbroek SE, Brown GD, Gordon S, Wong SY. 2005. Dectin-2 is predominantly myeloid restricted and exhibits 
unique activation-dependent expression on maturing inflammatory monocytes elicited in vivo. Eur J Immunol 35:2163-2174

Taylor PR, Tsoni SV, Willment JA, Dennehy KM, Rosas M, Findon H, Haynes K, Steele C, Botto M, Gordon S, Brown GD. 2007. Dectin-1 is required for beta-glucan recognition and control of fungal infection. Nat Immunol 8:31-38.

Tenner AJ. 1999. Membrane receptors for soluble defense collagens. Curr Opin Immunol 11:34-41.

Town T, Jeng D, Alexopoulou L, Tan J, Flavell RA. 2006. Microglia recognize double-stranded RNA via TLR3. J Immunol 176:38043812.

Traub S, Kubasch N, Morath S, Kresse M, Hartung T, Schmidt RR, Hermann C. 2004. Structural requirements of synthetic muropeptides to synergise with LPS in cytokine induction. J Biol Chem 279:86948700

Traub S, von Aulock S, Hartung T, Hermann C. 2006. MDP and other muropeptides-direct and synergistic effects on the immune system. $\mathrm{J}$ Endotox Res 12:69-85.

Triantafilou M, Gamper FG, Haston RM, Mouratis MA, Morath S, Hartung T, Triantafilou K. 2006. Membrane sorting of toll-like receptor (TLR)-2/6 and TLR2/1 heterodimers at the cell surface determines heterotypic associations with CD36 and intracellular targeting. J Biol Chem 281:31002-1011.

Tuomanen E, Hengstler B, Zak O, Tomasz A. 1986. The role of complement in inflammation during experimental pneumococcal meningitis. Microb Pathog 1:15-32.

Turner MW. 2003. The role of mannose-binding lectin in health and disease. Mol Immunol 40:423-429.

van Beck J, Elward K, Gasque P. 2003. Activation of complement in the central nervous system: roles in neurodegeneration and neuroprotection. Ann N Y Acad Sci 992:56-71.

Werts C, Tapping RI, Mathison JC, Chuang TH, Kravchenko V, Sain Girons I, Haake DA, Godowski PJ, Hayashi F, Ozinsky A, Underhil DM, Kirschning CJ, Wagner H, Aderem A, Tobias PS, Ulevitch RJ. 2001. Leptospiral lipopolysaccharide activates cells through a TLR2-dependent mechanism. Nat Immunol 2:346-352.

Wyss-Coray T, Yan F, Lin AH, Lambris JD, Alexander JJ, Quigg RJ, Masliah E. 2002. Prominent neurodegeneration and increased plaque formation in complement-inhibited Alzheimer's mice. Proc Natl Acad Sci U S A 99:10837-10842.
Yamamoto M, Sato S, Hemmi H, Uematsu S, Hoshino K, Kaisho T, Takeuchi O, Takeda K, Akira S. 2003. TRAM is specifically involved in the Toll-like receptor 4-mediated MyD88-independent signaling pathway. Nat Immunol 4:1144-1150.

Yoneyama M, Kikuchi $M$, Natsukawa $T$, Shinobu $N$, Imaizumi $T$, Miyagishi M, Taira K, Akira S, Fujita T. 2004. The RNA helicase RIG-I has an essential function in double-stranded RNA-induced innate antiviral responses. Nat Immunol 5:730-737.

Zekki H, Feinstein DL, Rivest S. 2002. The clinical course of experimental autoimmune encephalomyelitis is associated with a profound and sustained transcriptional activation of the genes encoding toll-like receptor 2 and CD14 in the mouse CNS. Brain Pathol 12:308-319.

Zhang SY, Jouanguy E, Ugolini S, Smahi A, Elain G, Romero P, Segal D, Sancho-Shimizu V, Lorenzo L, Pucl A, Picard C, Chapgier A, Plancoulaine S, Titeux $\mathrm{M}$, Cognet $\mathrm{C}$, von Bernuth $\mathrm{H}, \mathrm{Ku} \mathrm{CL}$, Casrouge A, Zhang XX, Barreiro L, Leonard J, Hamilton C, Lebon P, Héron B, Vallée L, Quintana-Murci L, Hovnanian A, Rozenberg F, Vivier E, Geissmann F, Tardieu M, Abel L, Casanova JL. 2007. TLR3 deficiency in patients with herpes simplex encephalitis. Science 317:1522.

Zhang X, Kimura Y, Fang C, Zhou L, Sfyroera G, Lambris JD, Wetsel RA, Miwa T, Song WC. 2007. Regulation of Toll-like receptor-mediated inflammatory response by complement in vivo. Blood 110:228236.

Zhang Z, Trautmann K, Schluesener HJ. 2005. Spinal cord glia activation following peripheral polyinosine-polycytidylic acid administration. Neuroreport 16:1495-1499.

Zhou H, Lapointe BM, Clark SR, Zbytnuik L, Kubes P. 2006. A requirement for microglial TLR4 in leukocyte recruitment into brain in response to lipopolysaccharide. J Immunol 177:8103-8110.

Zhou T, Chen Y, Hao L, Zhang Y. 2006. DC-SIGN and immunoregulation. Cell Mol Immunol 3:279-283.

Zimmer H, Riese S, Regnier-Vigouroux A. 2003. Functional characterization of mannose receptor expressed by immunocompetent mouse microglia. Glia 42:89-100.

Zwahlen A, Nydegger UE, Vaudaux P, Lambert PH, Waldvogel FA 1982. Complement-mediated opsonic activity in normal and infected human cerebrospinal fluid: early response during bacterial meningitis J Infect Dis 145:635-646. 